\title{
SLONDOK NUTRIHERBA : INOVASI SLONDOK MENGGUNAKAN BAHAN TAMBAHAN DAUN KELOR, WORTEL DAN IKAN TUNA UNTUK MENINGKATKAN KUALITAS PRODUK
}

\author{
Septian Emma Dwi Jatmika ${ }^{1}$, Hardi Astuti Witasari ${ }^{2}$, \\ ${ }^{I}$ Fakultas Kesehatan Masyarakat, Universitas Ahmad Dahlan, Jl. Prof. Dr. Seopomo, S.H., Janturan, \\ Warungboto, Umbulharjo, Yogyakarta \\ ${ }^{1}$ septianemmadikm.uad.ac.id \\ ${ }^{2}$ Fakultas Farmasi, Unversitas Ahmad Dahlan, Jl. Prof. Dr. Seopomo, S.H., Janturan, Warungboto, \\ Umbulharjo, Yogyakarta \\ ${ }^{2}$ witasari.hardiegmail.com
}

\begin{abstract}
Abstrak
Terdapat beberapa permasalahan yang ditemukan terkait dengan produksi slondok yang dihasilkan di Desa Harjobinangun, Kecamatan Pakem, Kabupaten Sleman. Permasalah tersebut antara lain belum penggunaan alat produksi yang masih sederhan, belum ada inovasi dan deversifikasi produk, nilai gizi yang masih relatif rendah, belum ada ijin P-IRT, pengemasan yang masih sederhana, pemasaran yang masih konvensional dan pengelolaan keuangan yang masih belum tertata dengan baik. Dengan demikian, tim pengusung menawarkan solusi alternatif untuk mengatasi permasalah tersebut dengan melakukan pemberdayaan kepada masyarakat melalui kegiatan pelatihan dan pembinaan pembuatan inovasi slondok nutriherba di Desa Harjobinangun. Program pemberdayaan ini bertujuan untuk meningkatkan pendapatan masyarakat dengan mengoptimalkan usaha rumah tangga yang berakar pada kearifan lokal dan budaya turun temurun. Kelompok sasaran adalah di IbuIbu PKK Dusun Blembeng Lor dan Kelompok Wanita Tani (KWT) Dusun Klarangan, Desa Harjobinangun. Metode yang diterapkan adalah pelatihan dan pendampingan, gelar dan launching produk serta evaluasi pelaksanaan dan keberlanjutan program. Hasil program pemberdayaan cukup bagus dilihat dari hasil evaluasi proses pelaksanaan berdasarakan tingkat pemahaman warga tentang proses pembuatan slondok. Terdapat peningkatan pengetahuan warga setelah diberikan pelatihan slondok sebesar $96,55 \%$ setelah mengikuti kegiatan pelatihan. Dengan demikian, dapat disimpulkan bahwa warga dapat memahami dengan baik materi yang disampaikan dalam pelatihan. Selain itu, slondok hasil produksi warga binaanpun diterima dengan baik oleh pasar, yang dibuktikan dengan keuntungan yang diperoleh warga dari hasil penjualan saat dilakukan gelar dan launching produk. Warga sangat antusias mengikuti setiap rangkaiaan kegiatan pemberdayaan ini.
\end{abstract}

Kata kunci: inovasi produk, pelatihan, pemberdayaan masyarakat, pendampingan, slondok nutriherba

\section{PENDAHULUAN}

Slondok merupakan salah satu makanan ringan yang diproduksi turun menurun dan menjadi salah satu warisan budaya masyarakat di Desa Harjobinangun, Kecamatan Pakem, Sleman. Desa Harjobinangun sebagai salah satu kawasan wisata yang berlokasi di lereng Gunung Merapi semakin populer, terlebih paska erupsi tahun 2012. Hal ini dimanfaatkan oleh warga untuk mengenalkan slondok sebagai makanan khas dari Desa Harjobinangun. Slondok merupakan salah satu jenis oleh-oleh pilihan yang renyah, gurih, dan memiliki kelebihan dapat bertahan lama meskipun tanpa bahan pengawet.

Pemerintah Desa Harjobinangun memberikan penguatan kepada para pengrajin dengan mendirikan kelompok-kelompok pengrajin slondok. Pemerintah desa berharap dengan pendirian kelompok pengrajin ini, akan terjalin kerjasama dan meminimalkan persaingan yang tidak sehat. Dengan adanya kelompok pengrajin, pembinaan dan koordinasi juga dapat lebih mudah dilakukan. Semua ini dilakukan oleh pemerintah Desa dalam rangka meningkatkan kesejahteraan masyarakat. Kelompok pengrajin slondok di Desa Harjobinangun yang sudah rutin mengadakan kegiatan produksi diantaranya adalah Kelompok Wanita Tani (KWT) di Dusun Klarangan dan Dusun Blembeng Lor. Dua KWT inilah yang menjadi sasaran program yang diusulkan. Tim pengusung bersama mitra melakukan identifikasi permasalahan terkait produksi slondok di Desa Harjobinangun yang kemudian dimusyawarahkan bersama tokoh masyarakat untuk menentukan prioritas masalah. Adapun prioritas masalah hasil musyawarah warga disajikan pada tabel I sebagai berikut.

Tabel I.

Prioritas Permasalahan yang diangkat untuk Kelompok Wanita Tani Dusun Klarangan dan Bembeng

\begin{tabular}{|l|l|l|}
\hline No & $\begin{array}{l}\text { Prioritas } \\
\text { masalah }\end{array}$ & $\begin{array}{l}\text { KWT Dusun Klarangan dan } \\
\text { Dusun Bembeng }\end{array}$ \\
\hline 1 & Produksi & $\begin{array}{l}\text { Proses produksi masih sangat } \\
\text { sederhana belum ada } \\
\text { sentuhan teknologi. }\end{array}$ \\
\hline
\end{tabular}




\begin{tabular}{|c|c|c|}
\hline 2 & Produk & $\begin{array}{l}\text { Produk masih original. Belum } \\
\text { ada inovasi dan deversifikasi } \\
\text { produk. }\end{array}$ \\
\hline 3 & $\begin{array}{l}\text { Kandungan } \\
\text { gizi }\end{array}$ & $\begin{array}{l}\text { Nilai gizinya relatif rendah } \\
\text { karena hanya terdiri atas } \\
\text { karbohidrat dari bahan ketela } \\
\text { saja. }\end{array}$ \\
\hline 4 & Ijin produk & $\begin{array}{l}\text { Belum ada ijin produk dari } \\
\text { Dinas Kesehatan }\end{array}$ \\
\hline 5 & Pengemasan & Pengemasan sangat sederhana \\
\hline 6 & Pemasaran & $\begin{array}{ll}\text { Pemasaran } & \text { masih } \\
\text { konvensional dengan } & \text { dititip } \\
\text { jual di kios-kios } & \\
\end{array}$ \\
\hline 7 & $\begin{array}{l}\text { Pengelolaan } \\
\text { keuangan }\end{array}$ & $\begin{array}{l}\text { Masih bercampur dengan } \\
\text { keuangan milik pribadi dan } \\
\text { rumah tangga }\end{array}$ \\
\hline
\end{tabular}

\section{TARGET DAN LUARAN}

Target capaian luaran pada program pemberdayaan ini adalah sebagai berikut :

1. KWT dapat melakukan proses produksi lebih banyak karena dibantu dengan mesin sederhana

2. KWT dapat menghasilkan slondok lezat kaya nutrisi rasa sayuran dan ikan

3. KWT dapat menghasilkan slondok lezat yang kaya akan protein, serat, beta karoten, zat besi dan antioksidan

4. KWT dapat menghasilkan slondok yang mempunyai ijin produksi oleh Dinas Kesehatan Kabupaten Sleman

5. KWT dapat menghasilkan slondok lezat dengan bahan pengemas yang aman, sehat dan menarik

6. KWT dapat melakukan pengelolaan keuangan secara profesional

7. KWT dapat memperluas pemasaran dengan melalui pemasaran yang konvensional maupun menggunakan social media dan online.

\section{METODE PELAKSANAAN}

Berdasarkan pada prioritas permasalahan yang dihadapi maka disusun metode pelaksanaan program yang mencakup bidang produksi, bidang menajemen, dan bidang pemasaran.

\section{A. Pelatihan dan Pendampingan}

Produksi merupakan modal awal dari sebuah usaha profit. Produk yang berkualitas akan memberikan kepuasan kepada konsumen dan menghadirkan konsumen baru. Oleh karena itu, peningkatan kualitas produk menjadi target dalam program pemberdayaan ini. Metode pelaksanaan program untuk peningkatan produksi disajikan pada tabel II sebagai berikut :
Tabel II.

Metode Pelaksanaan Program

\begin{tabular}{|c|c|c|}
\hline No & $\begin{array}{l}\text { Prioritas } \\
\text { permasalahan }\end{array}$ & Metode yang dilakukan \\
\hline 1 & Produksi & $\begin{array}{l}\text { Melakukan proses alih } \\
\text { teknologi menggunakan mesin } \\
\text { produksi sederhana yang } \\
\text { dikembangkan sesuai } \\
\text { kebutuhan pengrajin slondok. }\end{array}$ \\
\hline 2 & Produk & $\begin{array}{l}\text { Melakukan inovasi dan } \\
\text { deversifikasi slondok. Inovasi } \\
\text { dilakukan dengan } \\
\text { menambahkan sayuran dan } \\
\text { produk hewani yang kaya } \\
\text { nutrisi seperti daun kelor, daun } \\
\text { kenikir, wortel, ikan tuna, dll. }\end{array}$ \\
\hline 3 & $\begin{array}{l}\text { Kandungan } \\
\text { gizi }\end{array}$ & $\begin{array}{l}\text { Melakukan penambahan bahan } \\
\text { yang kaya nutrisi sehingga } \\
\text { slondok mempunyai kandungan } \\
\text { protein, serat, beta karoten, zat } \\
\text { besi, dan antioksidan }\end{array}$ \\
\hline 4 & Ijin produk & $\begin{array}{l}\text { Melakukan pendampingan } \\
\text { pengurusan ijin produksi ke } \\
\text { Dinas Kesehatan Kabupaten } \\
\text { Sleman }\end{array}$ \\
\hline 5 & Pengemasan & $\begin{array}{l}\text { Melakukan pelatihan dan } \\
\text { pendampingan untuk pemilihan } \\
\text { bahan pengemas yang aman dan } \\
\text { sehat serta cara pengemasan } \\
\text { yang menarik }\end{array}$ \\
\hline 6 & $\begin{array}{l}\text { Pengelolaan } \\
\text { keuangan }\end{array}$ & $\begin{array}{l}\text { Melakukan pelatihan dan } \\
\text { pendampingan sistem } \\
\text { pengelolaan keuangan yang } \\
\text { profesional }\end{array}$ \\
\hline 7 & Pemasaran & $\begin{array}{l}\text { Melakukan pelatihan dan } \\
\text { pendampingan pemasaran baik } \\
\text { secara konvensional maupun } \\
\text { dengan social media dan online }\end{array}$ \\
\hline
\end{tabular}

\section{B. Gelar Produk dan Launching Slondok} Nutriherba

Gelar produk dan launching slondok nutriherba dilaksanakan pada tanggal 16 September 2018 bersaam dengan agenda Jalan Sehat yang diselenggarakan oleh pemerintahan Desa Harjobinangan. Kegiatan ini bertujuan untuk mempromosikan inovasi slondok hasil produksi warga binaan. Acara ini dilaksanakan di Lapangan Desa Harjobinangun yang diharidi oleh segenap aparat pemerintah Desa Harjobinangun, beberapa tamu undangan dan seluruh masyarakat Desa Harjobinangun. Gelar produk yang diselenggarakan ini cukup menguntungkan karena warga binaan dapat mempromosikan slondok ke masyarakat luas dengan mudah. Warga bisa mendapat modal awal dari hasil penjualan slondok saat jalan sehat. Ini membuktikan bahwa slondok hasil produksi warga binaan dapat diterima dengan baik oleh masyarakat luas. Berikut adalah foto kegiatan pelaksanaan gelar dan launching produk slondok nutriherba : 


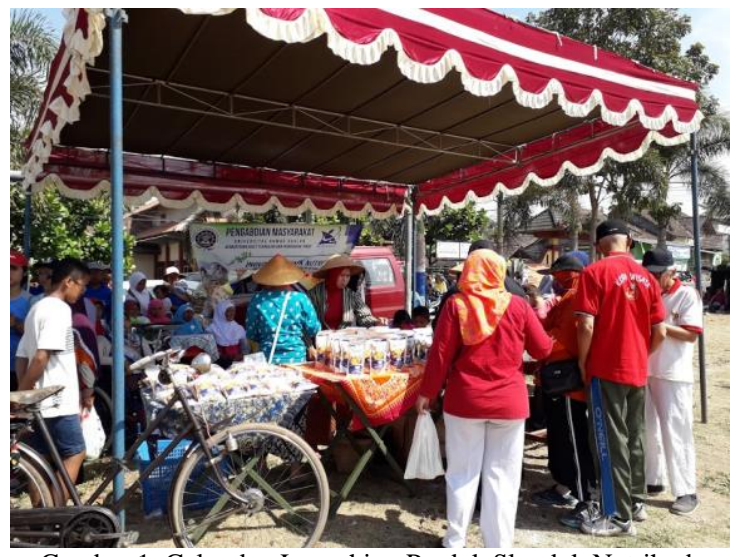

Gambar 1. Gelar dan Launching Produk Slondok Nutriherba

\section{Evaluasi Pelaksanaan Program dan Keberlanjutan Program}

Pelaksanaan program dievaluasi dengan menggunakan 2 cara. Untuk tingkat pemahaman anggota mitra maka evaluasi dilakukan dengan membandinkan skor pre dan post test. Selanjutnya akan dianalisis secara statistik. Untuk kemampuan ketrampilannya dilakukan pendampingan sampai program PKM ini selesai dilaksanakan.

Keberlanjutan program direncanakan akan diambil alih oleh pihak Pemerintah Desa. Pemerintah Desa mendukung penuh rencana kegiatan PKM ini dan dinyatakan dengan surat pernyataan dukungan. Pemerintah Desa Harjobinangun menyadari sepenuhnya bahwa program pemberdayaan masyarakat sejenis PKM ini sangat membantu pembangunan masyarakat.

\section{IV.HASIL DAN PEMBAHASAN}

Berikut ini adalah rangkaian kegiatan pengabdian kepada masyarakat di Desa Harjobinangun :

\section{A. Pelatihan Penggunaan Dan Pemeliharaan Mesin Produksi Slondok Nutriherba}

Proses produksi slondok yang dihasilkan warga selama ini menggunakan alat sederhan, sehingga secara kuantitif hasilnya kurang maksimal. Dengan demikian, perlu adanya sentuhan teknologi dalam proses produksi slondok nutriherba. Pada kegiatan ini tim pengusung mengenalkan mesin produksi slondok dan cara penggunaannya agar warga dapat membuat slondok nutriherba dengan cepat dan lebih efisien karena menggunakan mesin yang sederhana. Pada pelatihan ini disampaikan materi tentang cara menggunakan mesin dan pemeliharaannya. Setelah disampaikan materi tentang cara pengguanannya alat tersebut diberikan kepada kelompok pengrajin dan disertai penandatanganan berita acara serah terima oleh wakil dari LPM UAD dan Kepala Desa
Harjobinangun. Berikut ini adalah foto mesin produksi slondok yang dihahkan kepada warga binaan :

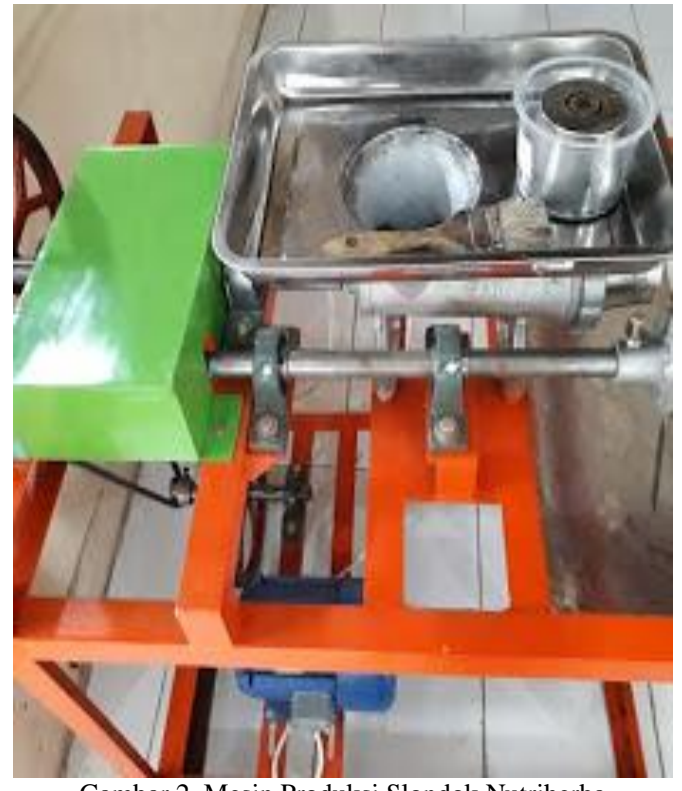

Gambar 2. Mesin Produksi Slondok Nutriherba

\section{B. Pelatihan dan Pendampingan Pembuatan Slondok Nutriherba}

Materi pelatihan pembuatan slondok nutriherba meliputi pemberian resep pembuatan slondok yaitu berupa bahan dasar slondok, campuran bahan daun kelor, wortel, dan ikan tuna. Selain itu juga dilanjutkan dengan pendampingan kepada pengrajin sehingga pengrajin lebih dapat memahami cara pembuatan slondok nutriherba ini.

Sebelum kegiatan pelatihan dilakukan, terlebih dahulu dilakukan penyuluhan atau penyampaian materi tentang slondok dan beberapa keuntungan dalam memproduksi slondok agar dapat meningkatkan pengetahuan masyarakat tentang produksi slondok. Penyampaian materi ini penting dilakukan agar masyarakat dapat memahami informasi apa saja yang dibutuhkan dalam memproduksi slondok yang baik dan memenuhi syarat beserta pengemasannya.

Untuk mengetahui tingkat pengetahuan dasar masyarakat tentang pembuatan slondok sebelum dilakukan penyampaian materi terlebih dahulu dilakukan penilaian tingkat pengetahuan masyarakat melalui pengisian kuesioner. Instrument tersebut berisi pertanyaan seputar proses pembuatan slondok. Tingkat pengetahuan warga sebelum dan sesudah dilakukan pelatihan slondok ditampilkan pada diagram I sebagai berikut : 
Diagram I.

Tingkat Pengetahuan Warga Sebelum dan Sesudah Pelatihan

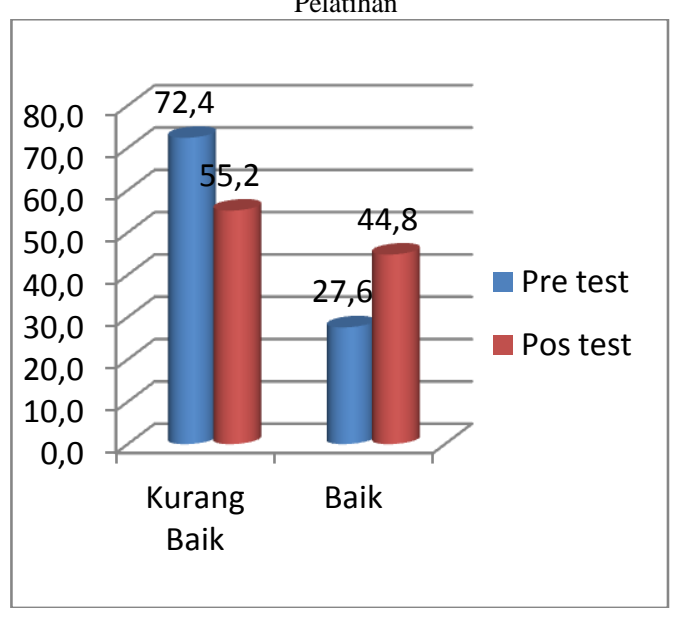

Berdasarkan diagram I diketahui bahwa persentase tingkat pengetahuan warga setelah dilakukan pelatihan lebih besar $(44,8 \%)$ dibanding persentase tingkat pengetahuan warga sebelum dilakukan pelatihan, yaitu sebesar $22,76 \%$. Persentasejurnal peningkatan tingkat pengetahuan wargadisajikan pada Tabel III sebagai berikut .

Tabel II.

Persentase Peningkatan Pengetahuan Warga Setelah diberikan

\begin{tabular}{|l|c|c|}
\multicolumn{1}{c}{$\begin{array}{c}\text { Hasil } \\
\text { pengetahuan }\end{array}$} & \multicolumn{2}{c|}{ Setelah pelatihan } \\
\hline & Jumlah & Persentase \\
\hline Menurun & 1 & $3,45 \%$ \\
\hline Meningkat & 28 & $96,55 \%$ \\
\hline Sama & 0 & $0 \%$ \\
\hline Jumlah & 29 & 100 \\
\hline
\end{tabular}

Berdasarkan tabel III diketahui bahwa pengetahuan warga setelah diberikan pelatihan slondok persentasenya meningkat hingga mencapai 96,55\% (28 orang). Dengan demikian, dapat disimpulkan bahwa warga dapat memahami dengan baik materi yang disampaikan dalam pelatihan. Berikut ini adalah foto kegiatan pelaksanaan pelatihan :

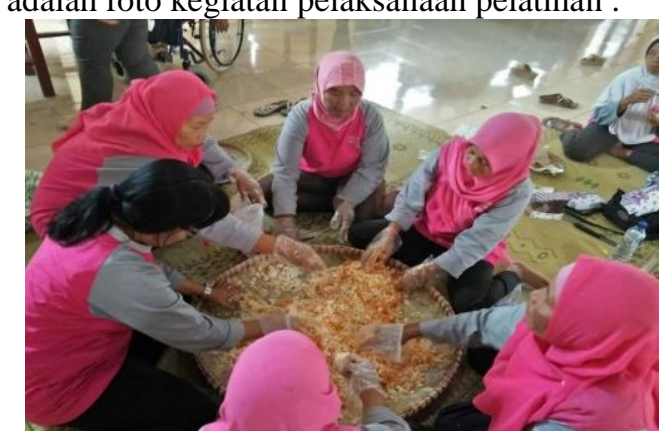

Gambar 3. Kegiatan Pelaksanaan Pelatihan Pembuatan Slondok Nutriherba

\section{Penyuluhan Kandungan Gizi Bahan Tambahan Slondok Nutriherba}

Bahan baku pembuatan slondok adalah ketela atau singkong. Namun selain bahan baku tersebut, untuk menhasilkan slondok yang kaya akan protein, serat, beta karoten, zat besi dan antioksidan maka diberikan inovasi atau campuran bahan seperti daun kelor, wortel, dan ikan tuna, agar slondok lebih lezat dan bergizi. Berikut adalah manfaat dari bahan-bahan yang ditambahkan, yaitu 1) Daun kelor memiliki manfaat untuk mencegah penyakit hati, menangkal radikla bebas, mencegah kanker, mengendalikan kadar gula darah, meredakan peradangan, menuurnkan kolesterol, dan melawan infeksi; 2) Wortel memiliki kandungan vitamin dan mineral, karbohidrat, serat dan senyawa lainnya yang meindungi tubuh dari sel kanker sehingga dapat mencegah penyakit jantung, berbagai jenis penyakit kanker, menjaga kesehatan mata, kekebalan tubuh, menjaga kesehatan otak, antiradang, antipenuaan dan kesehatan kulit serta menjaga kesehatan mulut; 3) Ikan tuna memiliki manfaat gizi yang sangat baik yaitu sumber protein yang lengkap, memiliki lemak yang baik karena dapat menyehatkan jantung, dan sumber mineral (Anindyaputri, 2017; Puji, 2018 dan Setiaji, 2018). Dengan demikian, penambahan bahanbahan yang kaya akan nutrisi dapat meningkatkan kualitas produk slondok dari sisi manfaat. Berikut adalah foto kegiatan pelaksanaan pelatihan :

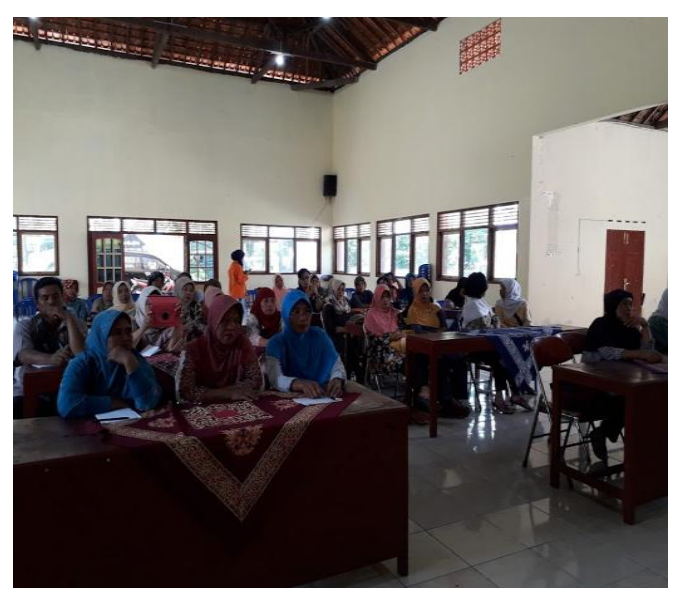

Gambar 4. Kegiatan Pelaksanaan Penyuluhan Kandungan Gizi Bahan Tambahan Slondok Nutriherba

\section{Pendampingan Pengurusan Ijin P-IRT Ke Dinas Kesehatan Kabupaten Sleman}

Produk makanan yang telah memiliki Nomor P-IRT tentunya lebih berkualitas. Hal ini dapat meningkatkan nilai jual produk. Dengan demikian, tim pengusung melakukan 
pendampingan untuk mengurus ijin P-IRT di Dinas Kesehatan Kabupaten Sleman. Pendampingan yang dilakukan meliputi pengkondisian rumah produksi slondok yang layak, pemberkasan syarat administrasi pendaftaran P-IRT, dan pendampingan uji kualitas air. Setelah itu Dinas Kesehatan akan melakukan visitasi ke rumah produksi warga hasil binaan. Jika lolos visitasi, warga akan diminta untuk mengikuti pelatihan. Adapun materi pelatihan meliputi Kebijakan Perundang-undangan, Cara produksi pangan yang baik, Hygiene dan sanitasi pangan, Pengawetan pangan, Pelabelan produk, Kemasan produk, Penggunaan bahan tambahan pangan dan Pembukuan.

E. Pelatihan Dan Pendampingan untuk Pemilihan Bahan Pengemas Yang Aman dan Sehat Serta Cara Pengemasan Yang Menarik

Materi pelatihan meliputi strategi pembuatan kemasan produk yang menarik. Pada kegiatan kali ini dilakukan penyuluhan menganai aneka macam pengemas yang aman untuk makanan dan menarik, baik untuk makanan panas maupun dingin. Jenis kemasan yang menjadi perhatian adalah plastik karena plastik banyak digunakan oleh masyarakat untuk mengemas makanan .

Selain jenis kemasan, materi berikutnya dalah tentang pembuatan label berasarkan Peraturan Pemerintah No. 69 Tahun 1999 tentang Label dan Iklan Pangan. Pada pelatihan ini, sasaran diajarkan cara membuat label yang memenuhi syarat PP No. 69 tersebut, baik syarat umum maupun syarat teknis. Persyaratan umum dari pembuatan label adalah harus jelas, mudah terlihat, dan berisi informasi yang benar, jujur dan akurat. Sementara itu, persyarat an teknis label adalah dibuat cukup besar agar memuat informasi penting mengenai produk, tidak mudah lepas, luntur atau lekang oleh air, gosokan atau sinar matahari, serta jika ditempelkan dengan lem, lem tidak boleh mempengaruhi mutu kemasan (misalnya men yebabkan karat) dan mutu label.

Materi berikutnya adalah jenis-jenis informasi yang dapat dicantumkan pada label makanan. Jenis informasi dibagi menjadi 2 bagian, yaitu bagian wajib dan bagian tambahan. Yang menjadi bagian wajib dari informasi tersebut adalah nama dagang, nama produk, berat bersih, nomor pendaftaran (PIRT, MD), serta nama dan alamat produsen, sedangkan bagian tambahan adalah tanggal kadaluarsa, kode produksi, komposisi, serta petunjuk cara pakai, penyimpanan, dan perawatan (Alsuhendra dan Ridawati, 2017). Berikut adalah kemasan Slondok Nutriherba hasil produksi warga binaan :

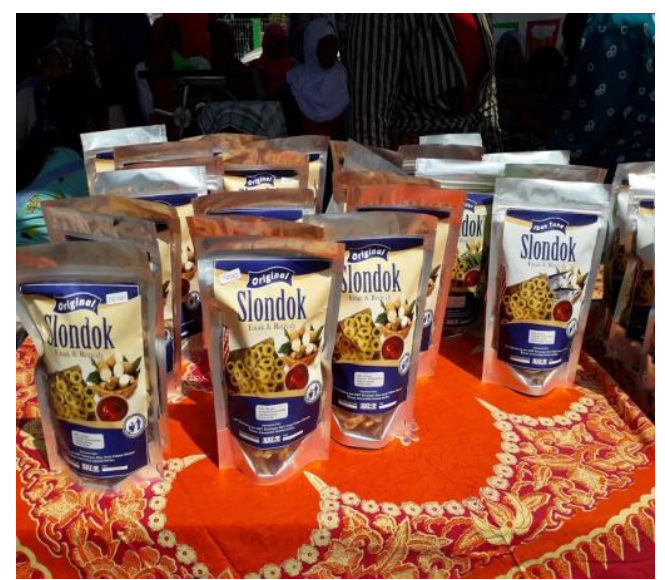

Gambar 5. Kemasan Slondok Nutriherba Hasil Produksi Warga Binaan

\section{F. Pelatihan dan Pendampingan Sistem Pengelolaan Keuangan Yang Profesional}

Tujuan kegiatan ini adalah warga dapat menghitung nilai harga pokok penjualan (hpp) slondok. Berdasarkan hasil perhitungan, didapatkan nilai hpp slondok per 100 gr adalah sebagai berikut : Slondok original dengan harga Rp 7500,00; Slondok Balado, Daun kelor dan wortel dengan harga masing-masing Rp 8000,00 sedangkan Slondok Tuna dengan harga Rp $8500,00 / 100$ gr. Berikut adalah foto kegiatan pelaksanaan pelatihan :

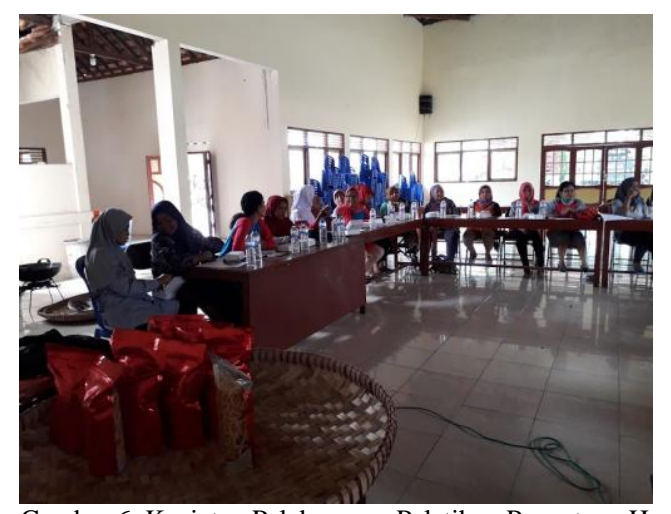

Gambar 6. Kegiatan Pelaksanaan Pelatihan Penentuan Hpp

\section{G. Pelatihan dan Pendampingan Pemasaran Produk}

Pelatihan ini guna memperluas pemasaran baik melalui pemasaran yang konvensional maupun menggunakan media sosial. Output kegiatan ini adalah pemanfaatan media sosial 
melalui whatsapp sebagai media alternatif untuk memasarkan slondok nutriherba. Pemasaran menggunakan media sosial merupakan sarana untuk mempromosikan suatu produk atau jasa secara lebih spesifik dan sebagai sarana untuk membangun target pasar melalui bisnis online . Harapannya, jangkauan pemasaran slondok nutriherba pun bisa lebih luas. Berikut adalah foto kebersamaan warga binaan setelah mengikuti kegiatan pelaksaaan pelatihan pemasaran produk :

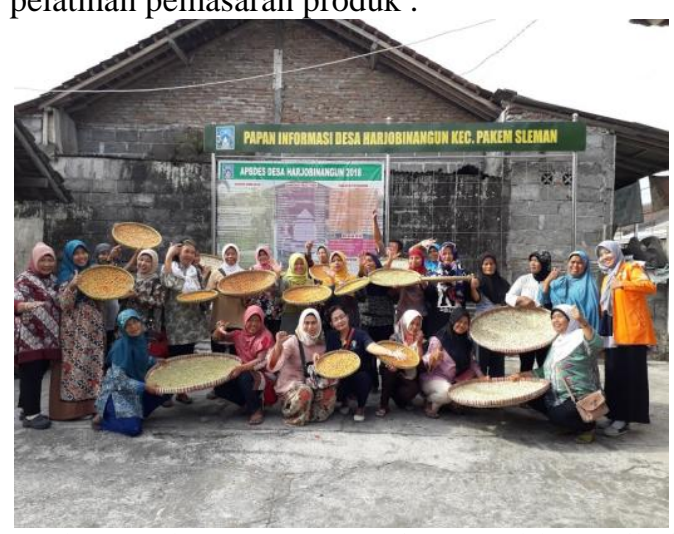

Gambar 7. Kebersamaan Warga Binaan Setelah Mengikut Kegiatan Pelaksaaan Pelatihan Pemasaran Produk

\section{KESIMPULAN}

Berdasarkan pelaksanaan program pemberdayaan masyarakat di Dusun Klarangan dan Dusun Bembeng dalam pembuatan slondok nutriherba diperoleh hasil sebagai berikut :
1. Masyarakat memiliki
ketrampilan memproduksi slondok nutriherba.

2. Adanya peningkatan kualitas produk setelah ditambah campuran bahan seperti daun kelor, wortel dan ikan tuna sehingga slondok memiliki khasiat lebih bergizi.

\section{UCAPAN TERIMA KASIH}

Terima kasih kami ucapkan kepada Kemenristek Dikti yang telah mendanai program PKM 2018.

\section{DAFTAR PUSTAKA}

[1] Alsuhendra dan Ridawati, 2017. Pelatihan Pembuatan Kemasan Dan Label Makanan Bagi Pelaku Usaha Makanan Di Desa Jampang, Kecamatan Kemang, Kabupaten Bogor. Jurnal Sarwahita Vol. 14 No. 02 Hal : 85-93.

[2] Anindyaputri, Irene. 2017. 7 Manfaat Daun Kelor: Dari Melwawan Infeksi Hingga Menurunkan Kolesterol. https://hellosehat.com/hidup-sehat/fakta-unik/7-manfaatdaun-kelor/

[3] Peraturan Pemerintah RI No. 66 Tahun 1999 tentang Label dan Iklan Pangan

[4] Puji, Aprinda. 2018. Tak Cuma Menyehatkan Mata, 7 Khasit Ini Bikin Kita Ingin Makan Wortel. http:// https://hellosehat.com/hidup-sehat/tips-sehat/manfaatwortel-bagi-tubuh/

[5] Setiaji, Bamandhita Rahma. 2018. 4 Manfaat Ikan Tuna yang Tak Boleh ANda eatkan Begitu Saja. https://hellosehat.com/hidup-sehat/nutrisi/manfaat-ikantuna/ 